\title{
Evaluation of Missile Injuries in the Maxillofacial \\ Region in Mosul City-Iraq (2007-2011)
}
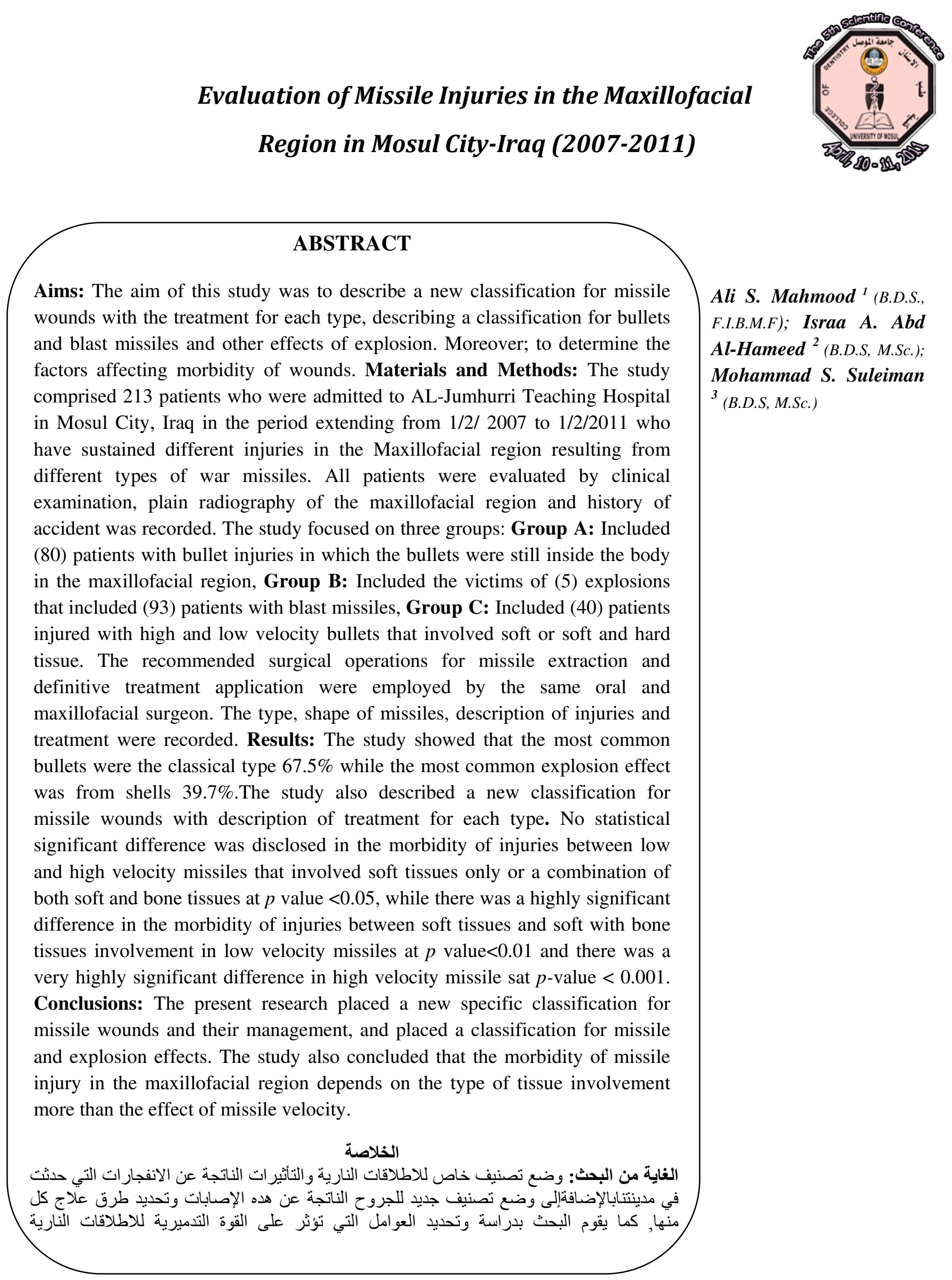

Ali S. Mahmood ${ }^{1}$ (B.D.S., F.I.B.M.F); Israa A. Abd Al-Hameed $^{2}$ (B.D.S, M.Sc.); Mohammad S. Suleiman

3 (B.D.S, M.Sc.)

Journal of the $5^{\text {th }}$ Scientific Conference of Dentistry College, Apr. 2011 


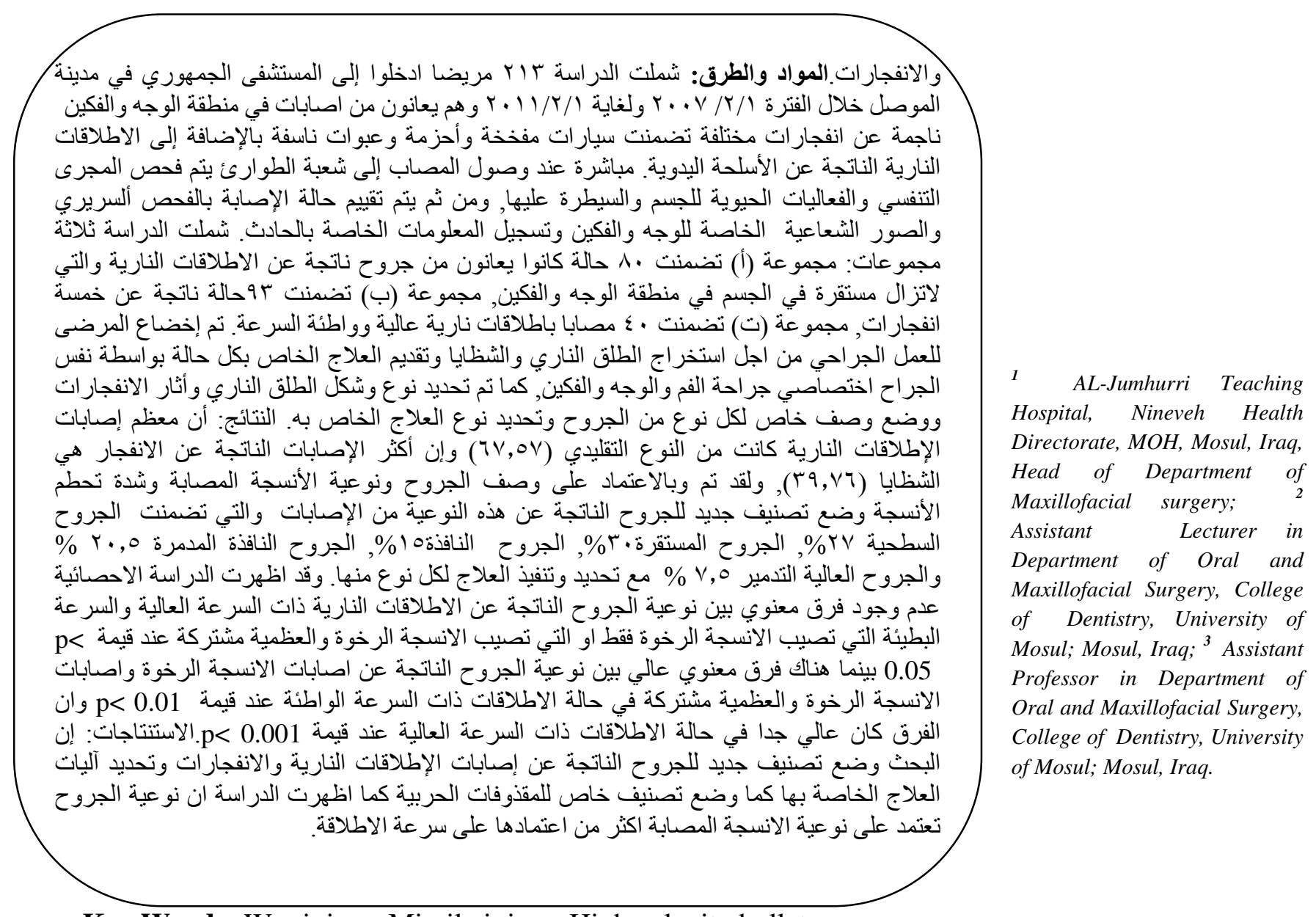

Key Words: War injury, Missile injury, High velocity bullet.

\section{INTRODUCTION}

ar has plagued humanity since the dawn of time ${ }^{(1)}$. Wounds of war generally
stem from injuries inflicted by projectiles from firearms. War wounds of the
maxillofacial region range from $8 \%$ to $15 \%{ }^{(2)}$. When a missile penetrates a
living body, the damage caused is the result of the absorption of the kinetic energy (KE), released from the missile, by the tissue. This transfer of energy is related to the mass $(\mathrm{M})$ and velocity $(\mathrm{V})$ of the missile ${ }^{(3)}$. The terms high and low velocity however can be misleading. For instance, a shotgun injury is technically a lowvelocity injury but is frequently responsible for major soft tissue, nerve, vascular and joint injuries. More useful is perhaps the use of low-energy and high-energy wounds, which are indicative of the amount of tissue damage sustained, suggesting the concept that energy transfer from the missile to the tissue is responsible for the severity of the wound ${ }^{(4)}$.The physical properties of a tissue through which a missile passes (tissue elasticity, density, cohesiveness and internal architecture), the diameter, shape, mass and velocity of the projectile, whether it expands into a mushroom shape or break-sand fragments and its internal construction are all primary determinants of wounding ${ }^{(5)}$. A center-fire "high-velocity" rifle bullet, if traverses only elastic tissue, such as skeletal muscle, it would not yaw significantly, would not fragment or deform and would not hit a major blood vessel or nerve. It fairly causes a minor wound. It will exit the extremity with most of its wounding potential unspent. If this same bullet hits a large bone, 
fragments and does not exit, it will crush a large volume of tissue and will create secondary missiles, such as bone fracture fragments, which also crush tissue and is likely to disrupt the neurovascular integrity of the wounded area, expending all its wounding potential in the patient and usually producing a severe wound ${ }^{(6)}$. If the wounded tissue is relatively elastic and cohesive, the amount of tissue crushed is the primary determinant of wounding ${ }^{(5)}$. All crushed tissue is killed. Tissue stretch (temporary cavitation) often has relatively little wounding effect in elastic cohesive tissue, such as skeletal muscle or lung. If an organ is non-elastic, near-water density and not very cohesive, such as brain or liver, temporary cavitation can cause a severe wound ${ }^{(6)}$.

An explosive is a material capable of producing an explosion by its own energy. Explosives produce heat and gas. An explosion or blast is followed by a sudden release of energy from a chemical, gaseous, mechanical or even nuclear means dissipated by a blast wave, propelling fragments and surrounding material, and causing heat formation ${ }^{(7)}$. Blast injuries fall into four main categories: Primary blast injury is related to the interaction of the initial shock wave with the body, secondary blast injury occurs as a result of the blast wave or wind and is caused by bomb fragments and other 'secondary' projectiles; while tertiary blast injury occurs as a result of gross body displacement ${ }^{(8)}$; lastly, the quaternary blast injury which is a miscellaneous collection of all other mechanisms. These include thermal injury to exposed skin caused by the heat of the explosion ${ }^{(9)}$.The treatment of these wounds is extremely complex. It incorporates optimal medical first aid, preserving vital functions, continuing care including definitive surgical and medical care of the wound; and rehabilitation, aiming to compensate functional damage and aesthetic defects ${ }^{(10)}$.

The Objectives of the Study: To report a specific classification for bullets and blast missiles and other effects of explosion that target community, in addition to reporting a new classification for missile wounds with determining and doing the treatment for each type. Moreover, to determine the factors affecting morbidity of wounds and to evaluate the distribution of missile injuries.

\section{MATERIALS AND METHODS}

The study comprised two hundred-thirteen patients who were admitted to AL-Jumhurri Hospital in Mosul City, Iraq in the period from 1/2/2007- 1/2/2011; sustaining different injuries in the Maxillofacial region resulting from different types of missiles which included car explosions, explosive belts, road side bomb, hand grenades, shells, fragments and bullets of manual machine guns. Immediately upon arrival in the medical unit, the patients' airway, breathing, and hemodynamic status was controlled .The airway was cleared, oxygenation and hemodynamic stabilization were achieved while the injuries were being assessed. All patients were evaluated by thorough clinical examination and plain radiography of the maxillofacial region. The history of accident was taken from the patient, if possible, or from his/her relatives. This included sum of information as shown in the data collection form (Figure 1). The emergency surgical treatment under local or general anesthesia was done in the following manner: control of significant bleeding if presented, copious irrigation with normal saline, cleaning the wound with wet gauze or brush, careful removal of the missile or bullet if presented, wound debridement that included removal of necrotic tissue, loose bone fragments which are completely detached from the periosteum and detached teeth, trimming the devitalized ragged skin edges, disinfection of the wound with povidone iodine, copious irrigation with saline, careful repair of the periosteum and covering the exposed bone with soft tissue and finally primary closure of the soft tissue wound without tension. Then, primary stabilization of bone 
with inter-maxillary fixation was performed, irrigation with saline, drain placement, packing the defect tissues with iodoform gauze, dressing the lacerated wound by sofratolwound dressing and sterile pack. Post- operative medications included antibiotics, analgesic sand steroids. After ten days, definitive treatment was carried out -when needed- as follows: Reconstruction of the damaged bone by titanium plates or wire and sometimes with bone graft, stabilization of jaws with inter-maxillary fixation and reconstruction of soft tissue loss with local flaps.

\section{Data Collection Form}

Patient No.: $\quad$ Age: $\quad$ Sex:

Type of missile: Bullet (Classical, abnormal shape, Blasting )

Blast (Blast wave, Blast wind, shells and fragments of blast, Foreign body)

Type of gun (if possible):

Bullet velocity: High Low

Type of tissue involvement: soft tissue only

bone and soft tissue

Type of blast wound: (Lacerated wound, Penetrated wound, Perforated wound, Destructive perforated wound, Highly destructive wound)

Type of bullet wound: (Perforated wound, Destructive Perforated wound, Highly Destructive wound)

Figure (1): Data Collection Form

\section{The patients were divided into three study groups:}

- Group A: This group included (80) patients with bullet injuries, whom the bullets or its contents were still inside the maxillofacial region. A specific classification was described according to the type and shape of bullets as follows:
a. Classical bullets Figure (2).
b. Abnormal shape bullets Figure (3).
c. Blasting bullets Figure (4).

- Group B: This group comprised the victims of (5) explosions that included (93) patients with blast missiles in the maxillofacial region resulting from two explosive cars, one explosive belt, one road side bomb and one hand grenades. According to the type of blast missiles and description of injuries, the study described a classification for the effects of explosion. Such effects include: 
a. Blast Wave: Caused by blast overpressure waves. These are especially likely when a person is close to an explosion. In maxillofacial region, the ears and eyes are most often to be affected by the overpressure.

b. Blast Wind: This includes the blast powder projectiles which are poisoned by bacteria and debris in addition to the post-blast flames (forced super-heated air flow) (Figure 5).

c. Foreign Bodies: These include the fragments and foreign bodies that are not related to blast material like glass, wood, stone, metal and plastic material (Figure6).

d. Shells and Fragments of Blast: These included the shells and metallic fragments that

e. presented around the blast material (Figures 7 and 8).
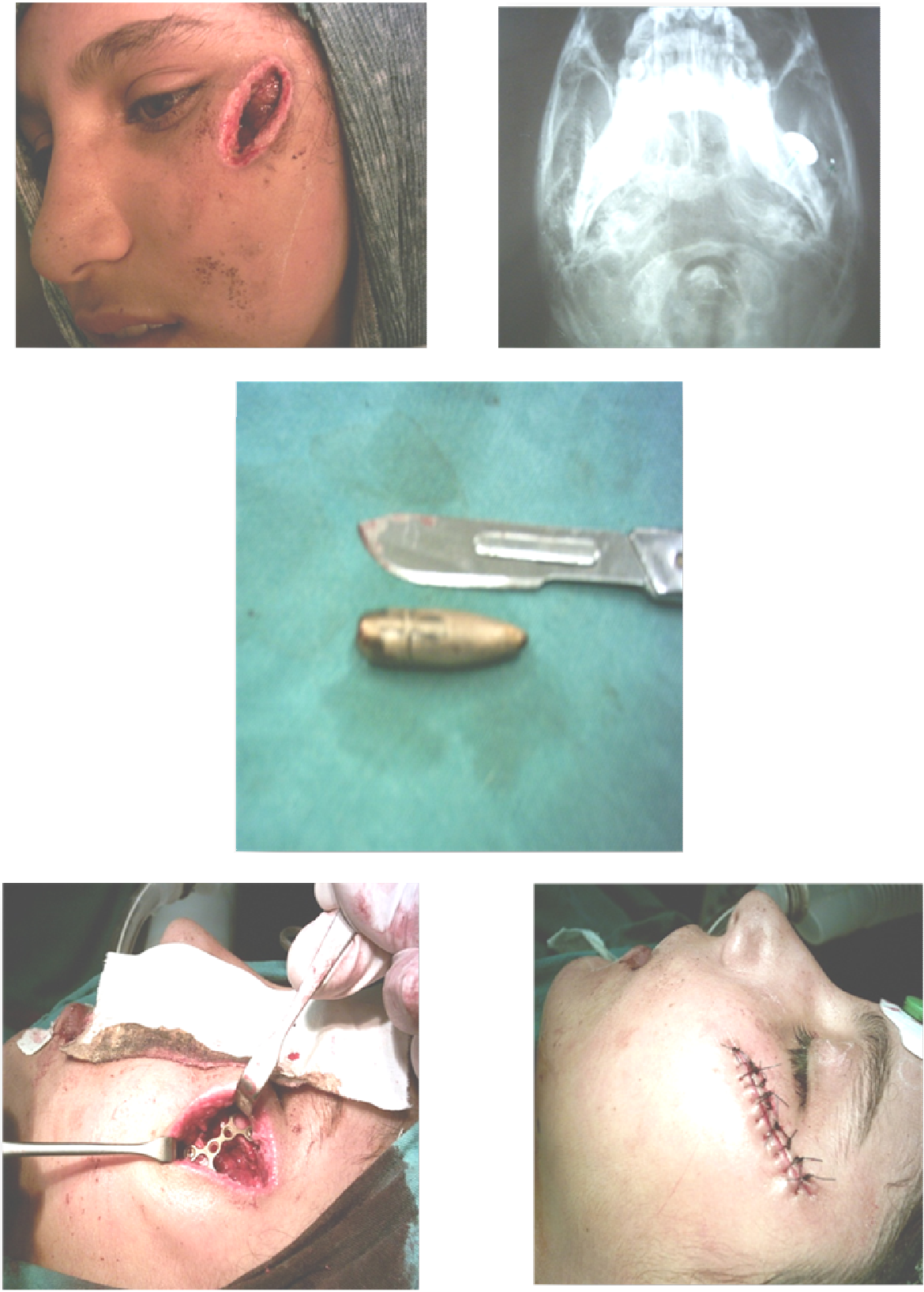

Figure 2: Penetrated Wound Resulted By Classical Bullet and Its Treatment

Journal of the $5^{\text {th }}$ Scientific Conference of Dentistry College, Apr. 2011 
Taha MY, Surchi O, Abdulaziz SM
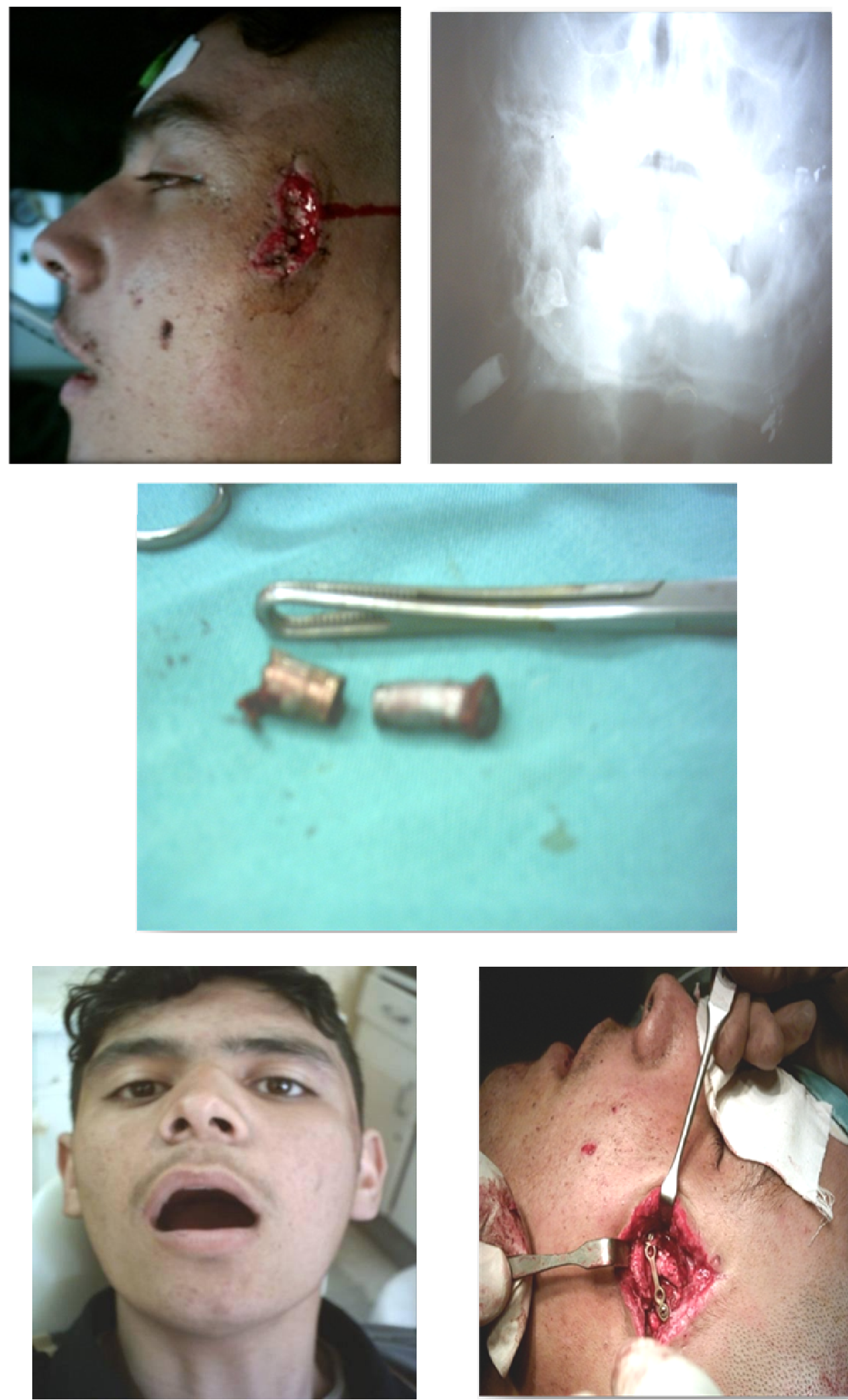

Figure 3: Penetrated Wound Resulted By Abnormal Shape Bullet and Its Treatment

Journal of the $5^{\text {th }}$ Scientific Conference of Dentistry College, Apr. 2011 
Taha MY, Surchi O, Abdulaziz SM
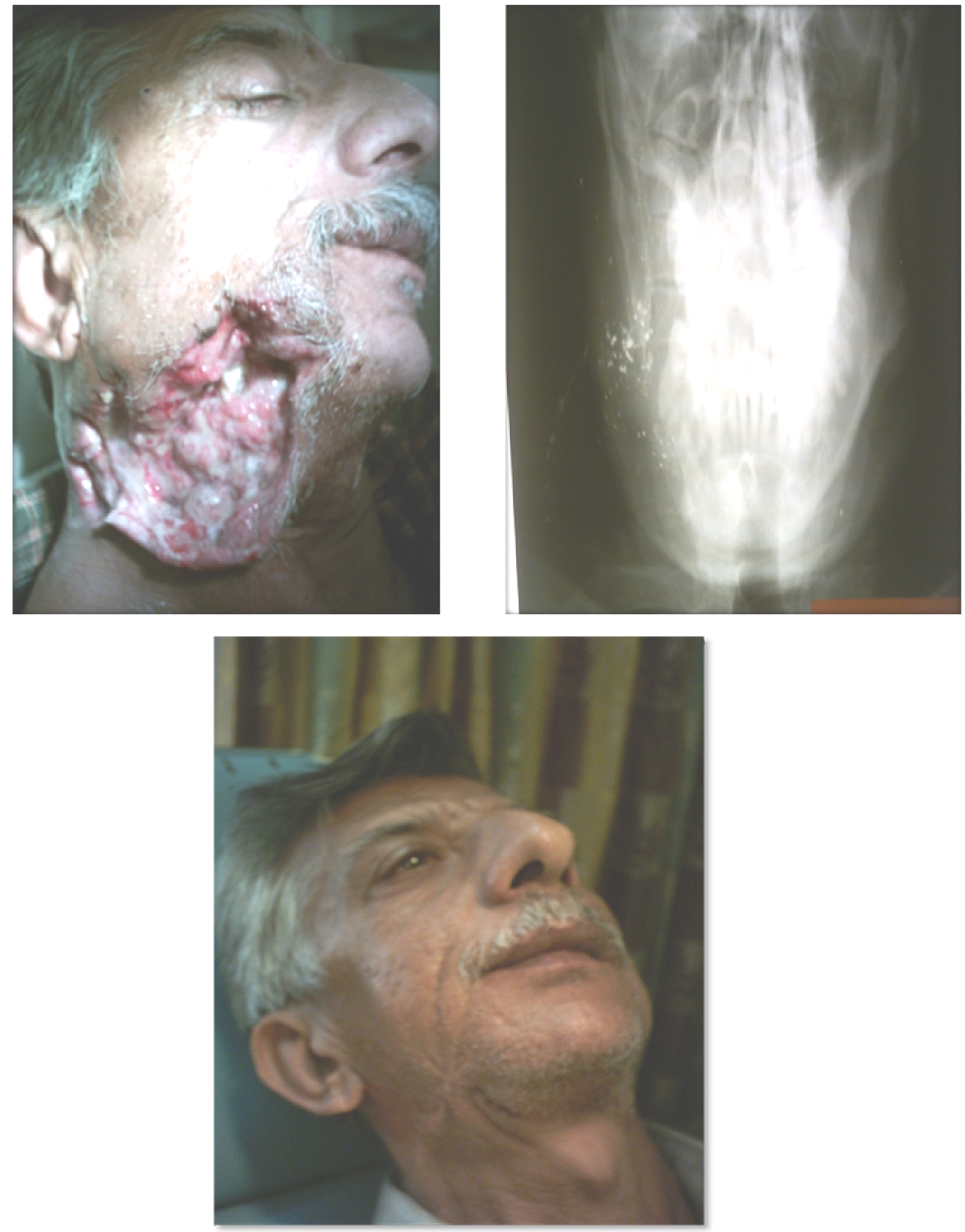

Figure 4: Wound Resulted by Blasting Bullet and Its Treatment

Journal of the $5^{\text {th }}$ Scientific Conference of Dentistry College, Apr. 2011 


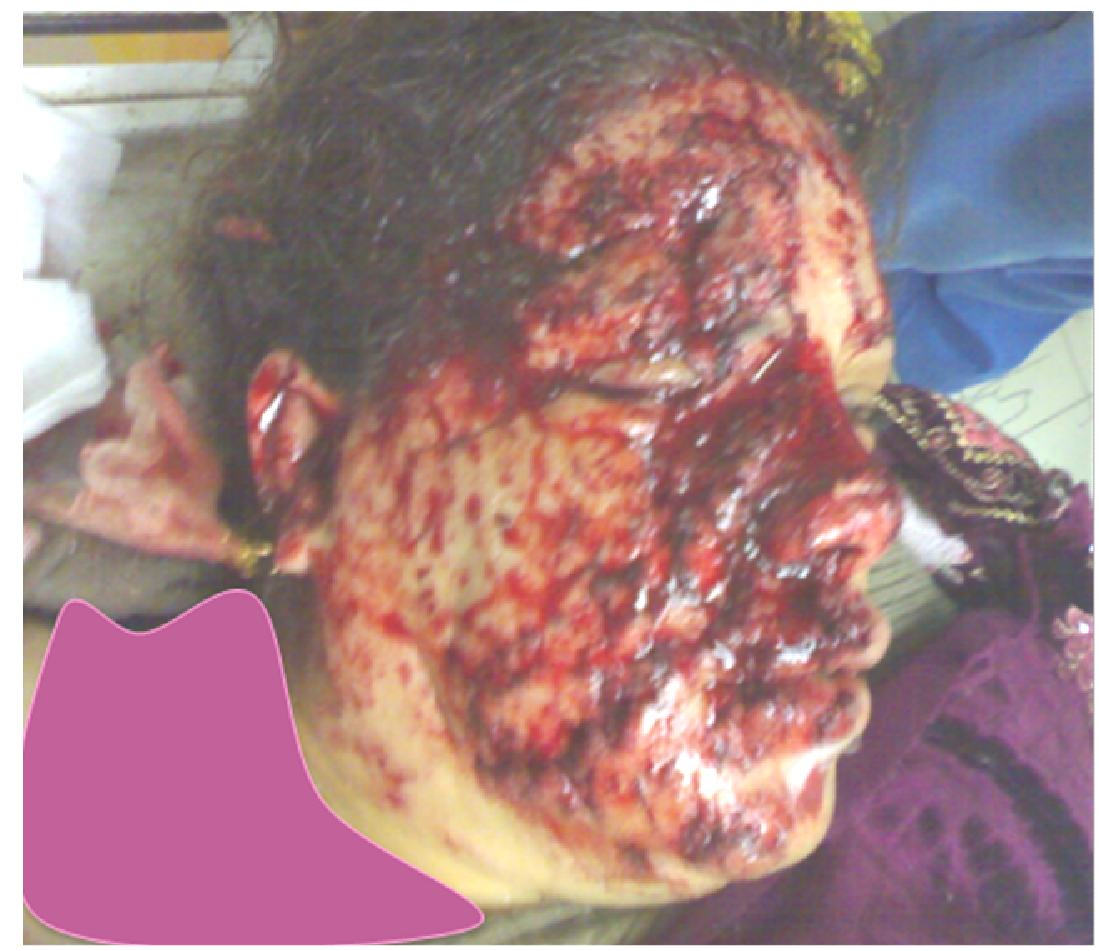

Figure 5: Lacerated Wound Resulted by Blast Wind

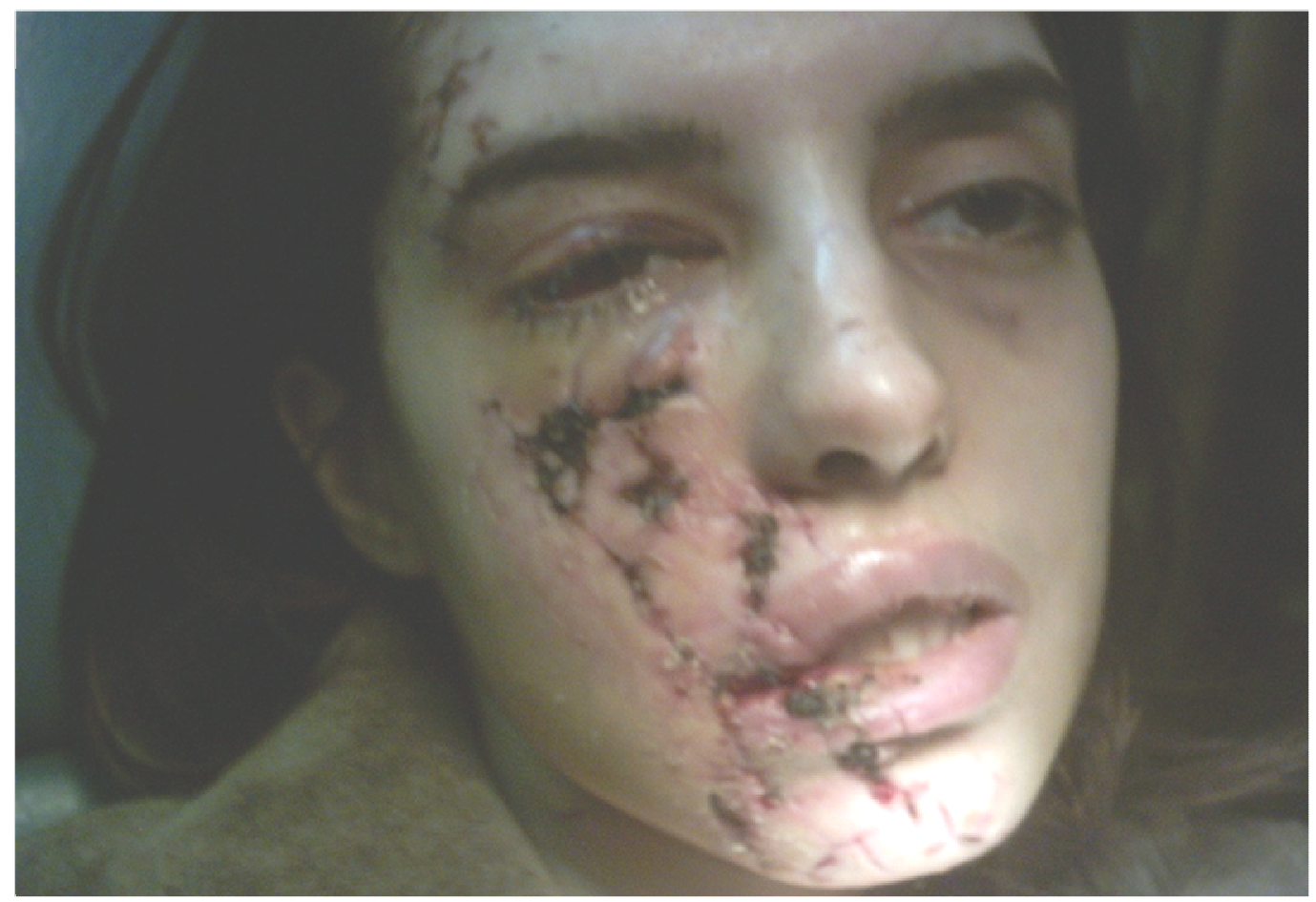

Figure 6: Penetrated Wound Resulted by Foreign Body

Journal of the $5^{\text {th }}$ Scientific Conference of Dentistry College, Apr. 2011 

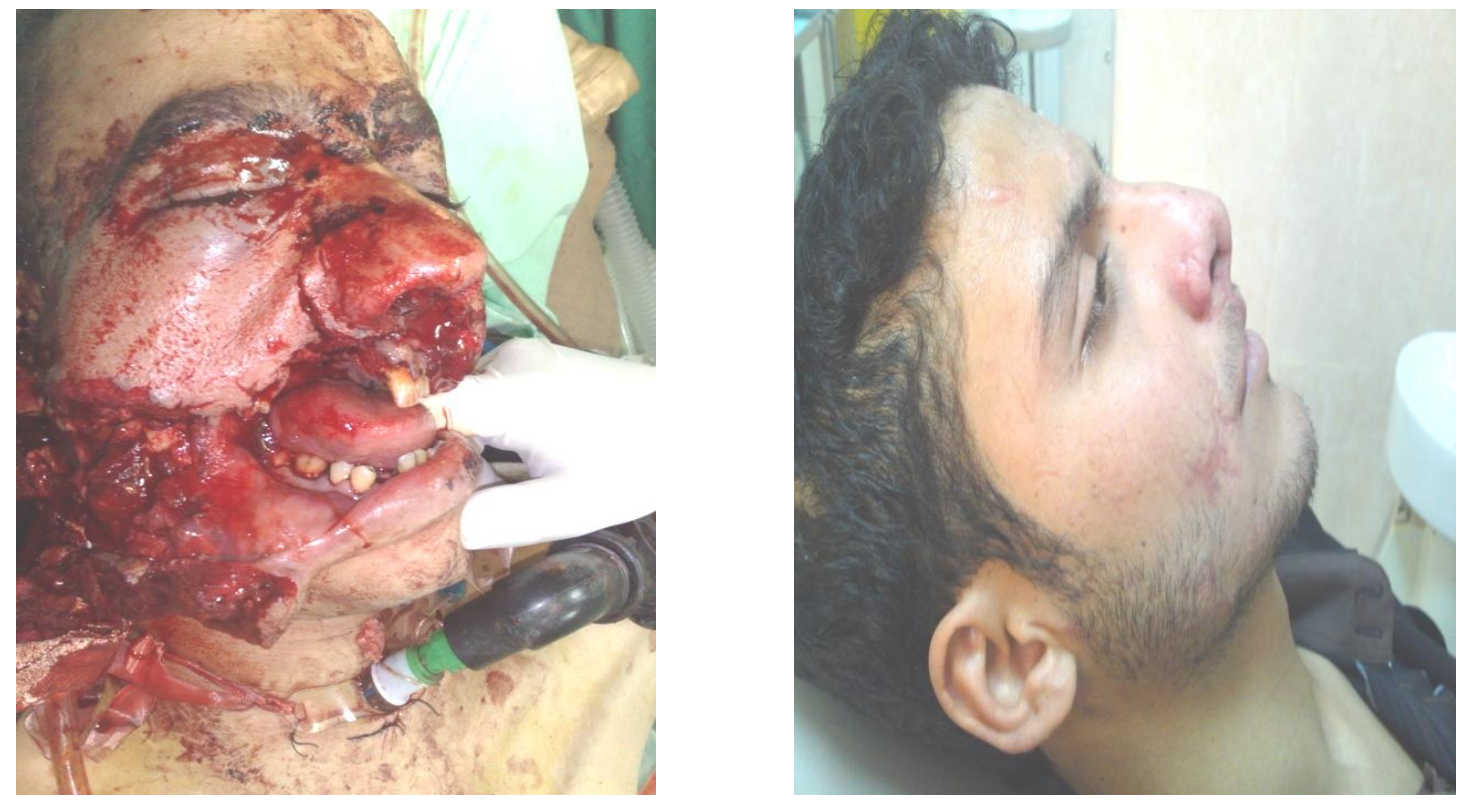

Figure 7: Destructive Perforated Wound Resulted By Shell and Post-Operative
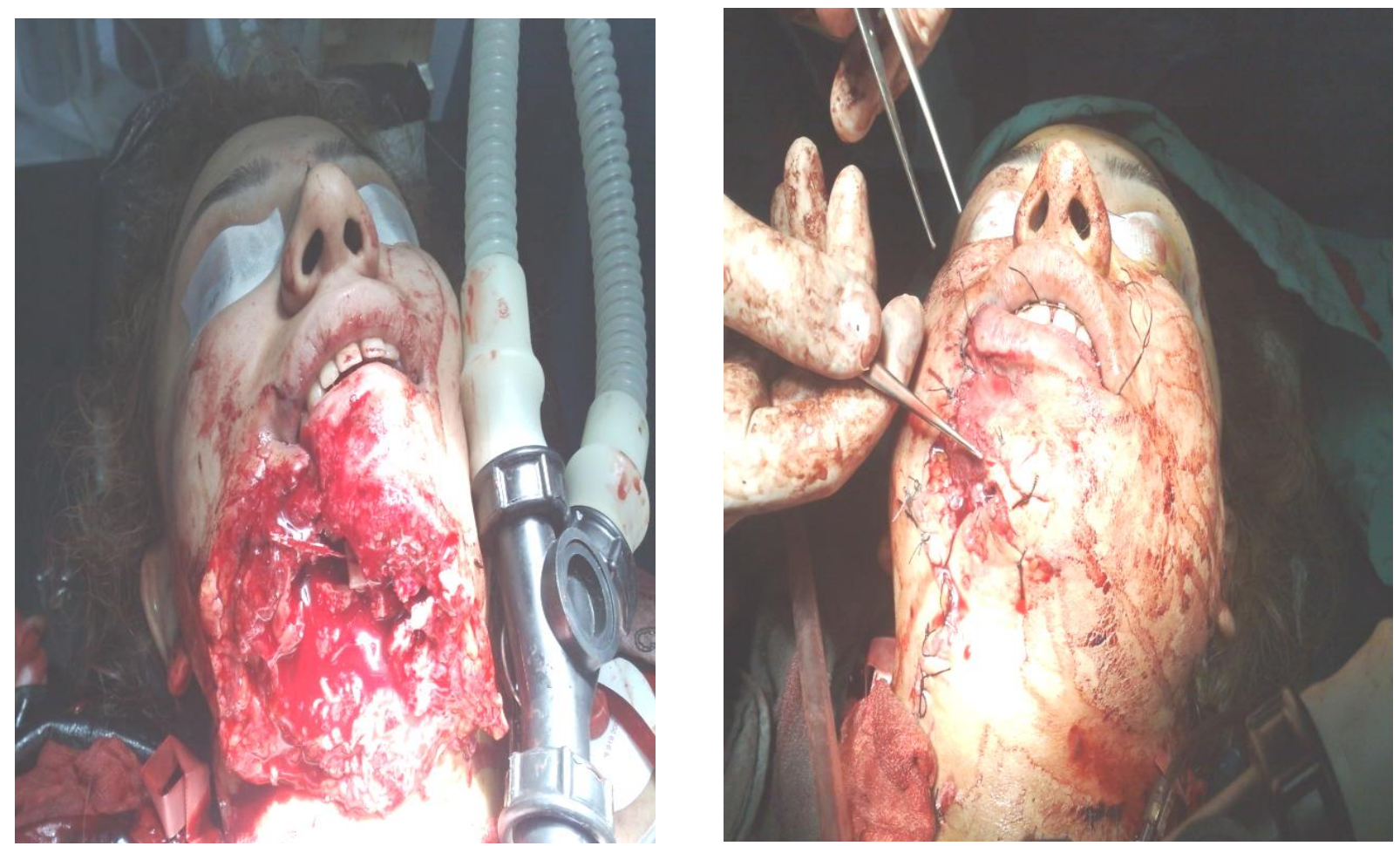

Figure 8: Highly Destructive Wound Resulted By Shell and Its Emergency

Treatment

Journal of the $5^{\text {th }}$ Scientific Conference of Dentistry College, Apr. 2011

245 
- to bullet and weapon velocity and type of tissue injury into:

C1: Included 10 patients injured with low velocity bullets that result in soft tissue injuries only (Figure 9).

C2: Included 10 patients injured with high velocity bullets that result in soft tissue injuries only (Figure 10).

C3: Included 10 patients injured with low velocity bullets that result in soft tissue and bone injuries (Figure 11).

C4: Included 10 patients injured with high velocity bullets that result in soft tissue and bone injuries (Figure 12).

Group C: This group included (40) patients of bullet injuries; those were divided according

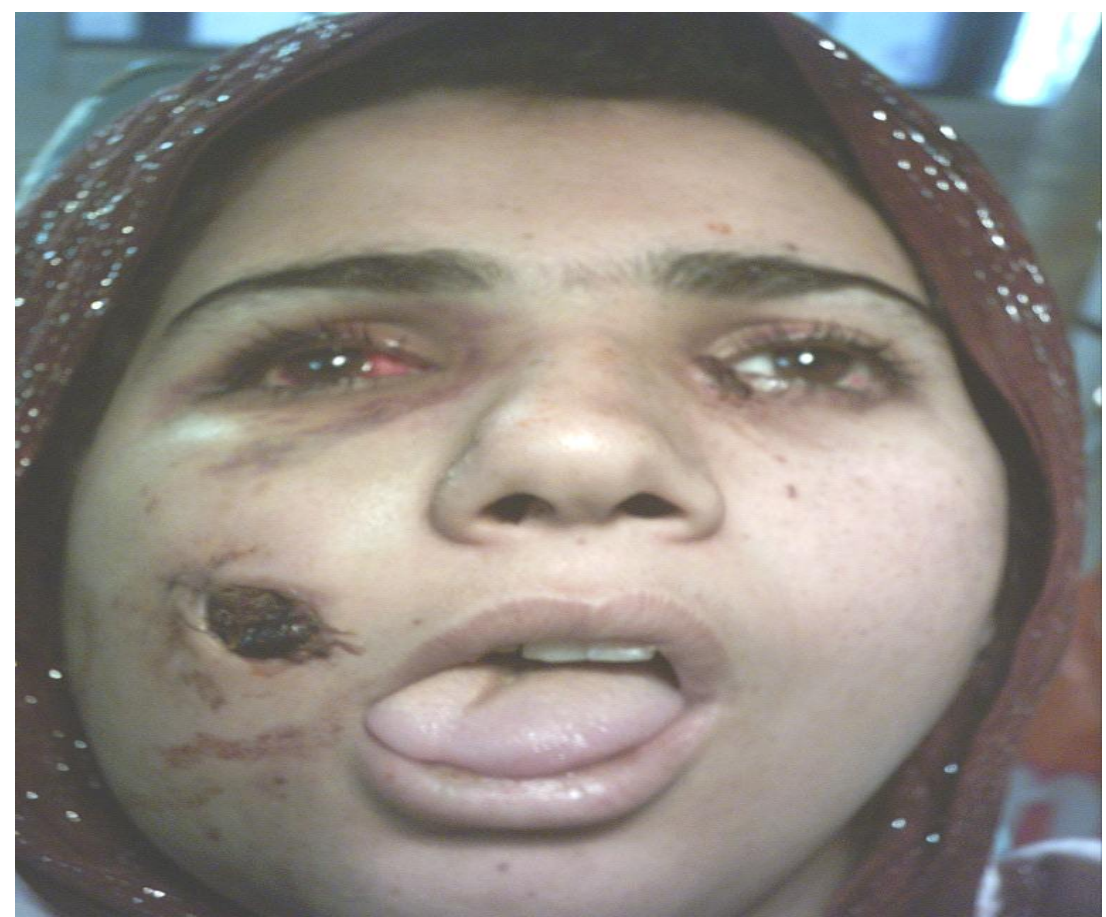

Figure 9: Perforated Wound (Soft Tissue Only) Resulted By Low Velocity Bullet 


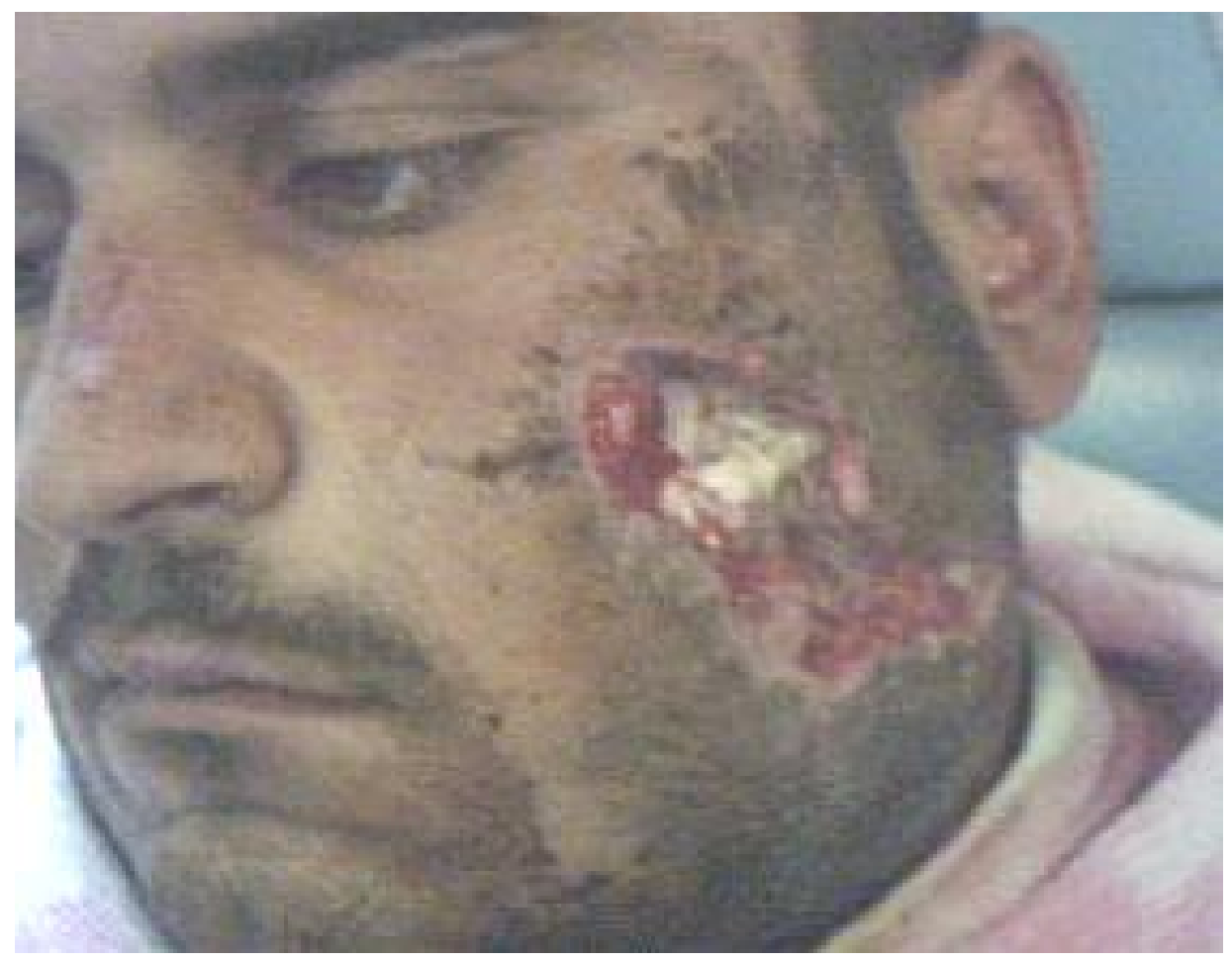

Figure 10: Destructive Perforated Wound (Soft Tissue Only) Resulted By High Velocity Bullet

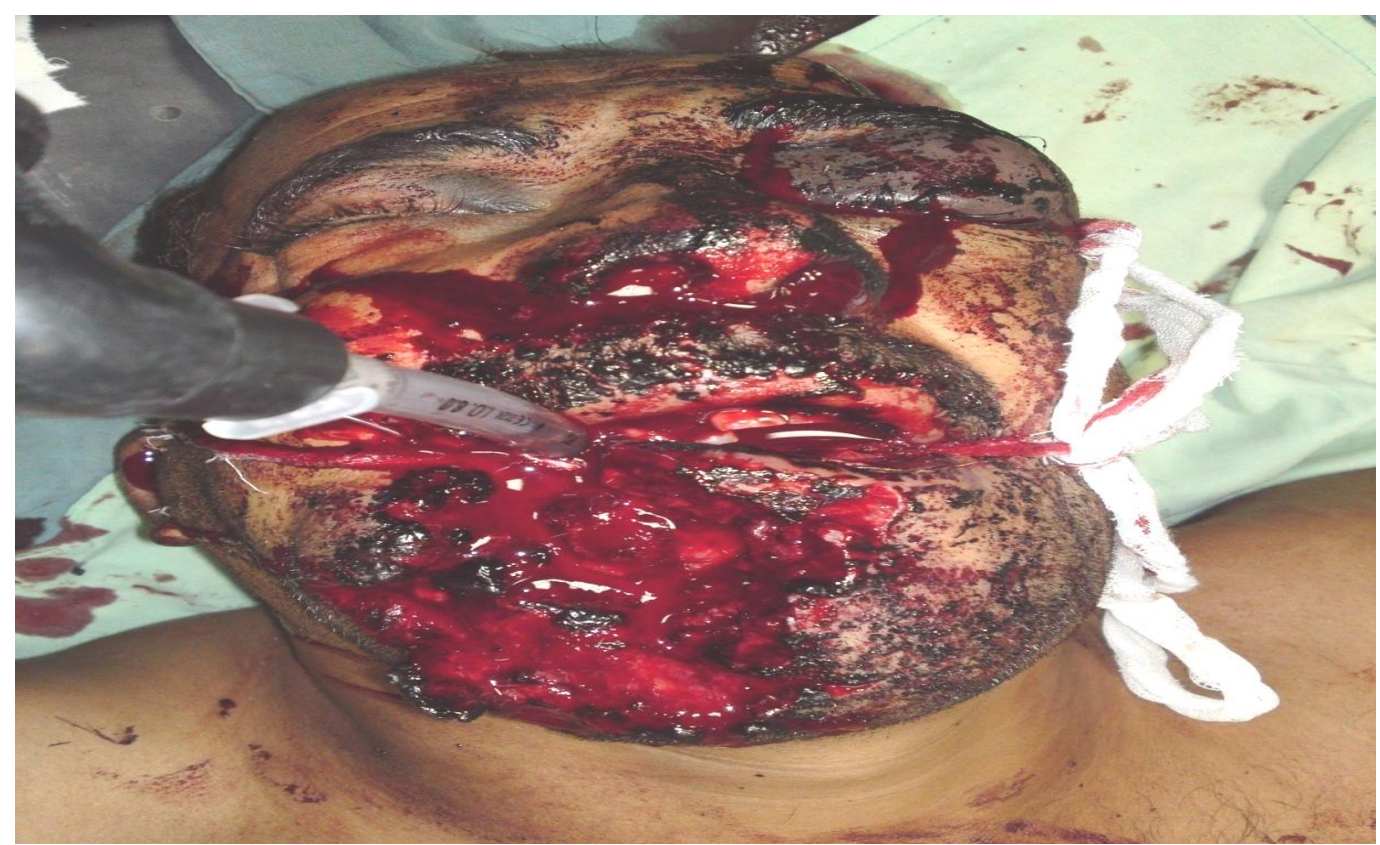

Figure 11: Highly Destructive Wound (Bone Involvement) Resulted By Low Velocity Bullet 


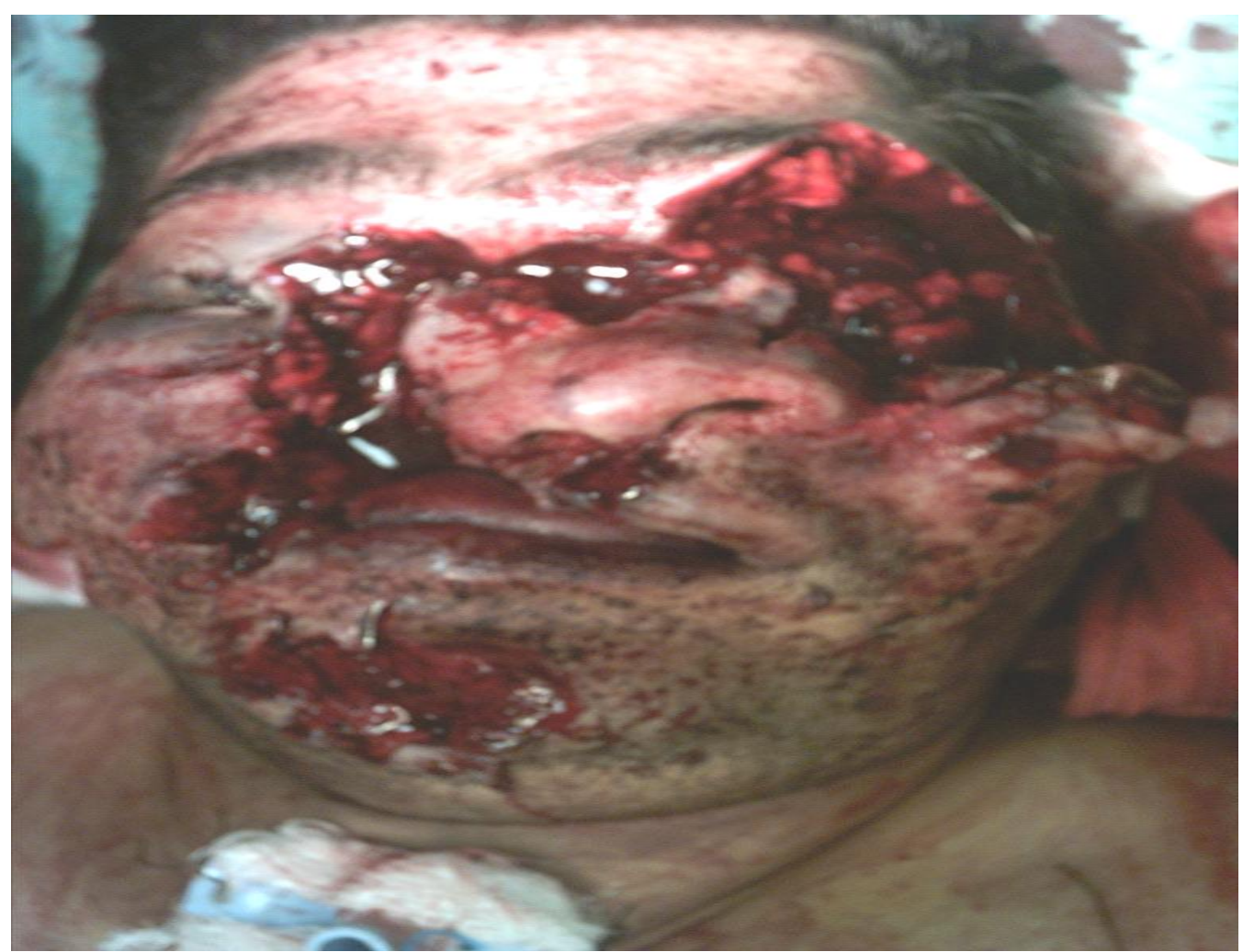

Figure 12: Highly Destructive Wound (Bone Involvement) Resulted By High Velocity Bullet

Unfortunately, we could not find a classification in previous studies that involves all types of wounds in the cases of the present research. In an attempt to involve all such types, we intended to classify missile (blast and bullet) injuries depending on the description of the wound, type of tissue involvement and the severity of tissue damage; this classification falls into 5 categories:

a. Lacerated Wound: In which the tissues are torn and sometimes burned as in Figure (5).

b. Penetrated Wound: In which the missile has penetrated the skin into the underlying tissues and remained there (Figure 6).

c. Perforated Wound: In which the wound has an entrance and an exit of missile through only soft tissue without tissue loss.

d. Destructive Perforated Wound: In which the wound has an entrance and an exit of missile with tissue loss in the exit side (Figure 7).

e. Highly Destructive Wound: These were specific injuries with severe damage of soft and hard tissues, with a loss of large amount of tissue in more than one third of face commonly leading to the death of victim due to the heavy damage of tissue which mainly extends to the brain or neck (Figure 8). 


\section{Statistical Analysis:}

Data were collected and managed by SPSS System (Statistical Package for Social Science) on Pentium Four computer. The Pearson Chi-Square Statistical test was done for study groups. The Significance was accepted for $(p \leq 0.05)$. When $(p<0.01)$, the results were considered as highly significant (H.S); while values less than $0.001 \quad(p<0.001)$ were considered to be very highly significant (V.H.S).

\section{RESULTS}

The sex distribution and age range of patients enrolled in the present research is shown in Table (1). The males represented $78 \%$ (166 patients) from all patients, while females constituted only $22 \%$ (47 patients) from the total. The age range of the male patients was (4 month -77 years) with a mean of 32 years; while the age range of female patients was ( 2 years -65 years) with a mean of 36 years.

Table (1): Sex Distribution and Age Range of Patients

\begin{tabular}{c|c|c|c}
\hline Sex & Number of Patients & Age Range & Mean Age \\
\hline Male & 166 & 4 Months -77 Years & 32 Years \\
\hline Female & 47 & 2 Years -65 Years & 36 Years
\end{tabular}

The results of bullet injuries in the maxillofacial region are illustrated in Table (2). The table shows that the classical bullets $(67 \%)$ were the most common type of bullets used.

Table (2) Types of Bullets

\begin{tabular}{c|c|c}
\hline Type of Bullet & Number of Patients & Percentage \% \\
\hline Classical bullet & 54 & $67 \%$ \\
\hline Blasting bullet & 23 & $28.7 \%$ \\
\hline Abnormal shape bullet & 13 & $16.3 \%$ \\
\hline Total & 80 & $100 \%$
\end{tabular}

The results associated with the number of patients injured as a result of explosion effects are shown in Table (3). This table shows that shells and fragments of blast were the most common cause of injuries (40\%) that result from explosions. 
Table (3): Causes of Injuries Resulting from Explosion

\begin{tabular}{c|c|c}
\hline $\begin{array}{c}\text { Causes of Injuries Resulting from } \\
\text { Explosion }\end{array}$ & Number of Patients & Percentage \% \\
\hline Blast Wave & 6 & $6.5 \%$ \\
\hline Blast Wind & 19 & $20.5 \%$ \\
\hline Shells And Fragments Of Blast & 37 & $40 \%$ \\
\hline Foreign bodies & 31 & $33 \%$ \\
\hline Total & 93 & $100 \%$
\end{tabular}

The number of patients affected by explosions in accordance to the type of missile wounds is shown in Table (4). The results revealed that penetrated wounds (PNW) were the most common (28 patients), followed by lacerated wound (LW) which included (25) patients, whereas the least number of patients (only 7) was recorded for highly destructive wound (HDW).

Table (4): Types of the Missile Wounds

\begin{tabular}{l|c|c}
\hline \multicolumn{1}{c|}{ Type of the Wound } & Number of Patients & Percentage \% \\
\hline Lacerated Wound ( LW ) & 25 & $27 \%$ \\
\hline Penetrated Wound ( PNW ) & 28 & $30 \%$ \\
\hline Perforated Wound ( PW ) & 14 & $15 \%$ \\
\hline Destructive Perforated Wound(DPW) & 19 & $20 \%$ \\
\hline Highly Destructive Wound ( HDW ) & 7 & $8 \%$ \\
\hline \multicolumn{1}{c}{ Total } & 93 & $100 \%$
\end{tabular}

Details concerning causes of injuries resulting from explosions and types of missile wounds are illustrated in Table (5), where only lacerated wounds were noticed as a result of blast wave (6 patients) and blast wind (19 patients). However, the most common missile wounds associated with shells and fragments of blast (13 patients) and foreign bodies (15 patients) were the penetrating $(\mathrm{PNW})$ ones. 
Table (5): The Relation between the Causes of Injuries Resulting from Explosion and Type of Wounds

\begin{tabular}{|c|c|c|c|c|c|c|c|c|c|c|c|}
\hline \multirow{3}{*}{ Blast } & \multicolumn{10}{|c|}{ Type of wounds } & \multirow{3}{*}{ Total } \\
\hline & \multicolumn{2}{|c|}{ Lacerated } & \multicolumn{2}{|c|}{ Penetrated } & \multicolumn{2}{|c|}{ Perforated } & \multicolumn{2}{|c|}{$\begin{array}{l}\text { Destructive } \\
\text { Perforated } \\
\end{array}$} & \multicolumn{2}{|c|}{$\begin{array}{c}\text { Highly } \\
\text { Destructive }\end{array}$} & \\
\hline & No. & $\%$ & No. & $\%$ & No. & $\%$ & No. & $\%$ & No. & $\%$ & \\
\hline $\begin{array}{l}\text { Blast } \\
\text { Wave }\end{array}$ & 6 & 100 & 0 & 0 & 0 & 0 & 0 & 0 & 0 & 0 & 6 \\
\hline $\begin{array}{l}\text { Blast } \\
\text { Wind }\end{array}$ & 19 & 100 & 0 & 0 & 0 & 0 & 0 & 0 & 0 & 0 & 19 \\
\hline Shell & 0 & 0 & 13 & 35.14 & 8 & 21.62 & 11 & 29.73 & 5 & 13.51 & 37 \\
\hline $\begin{array}{l}\text { Foreign } \\
\text { Body }\end{array}$ & 0 & 0 & 15 & 48.39 & 6 & 19.35 & 8 & 25.81 & 2 & 6.45 & 31 \\
\hline Total & 25 & 26.8 & 28 & 30.11 & 14 & 15.05 & 19 & 20.43 & 7 & 7.53 & 93 \\
\hline
\end{tabular}

The relation between factors of morbidity (type of tissue injury, bullet velocity) and the resultant wounds are showed in Tables (6) and (7).

Table (6): The Relation between the Factor of Morbidity (Type of Tissue Injury) and Type of Wound

\begin{tabular}{|c|c|c|c|c|c|}
\hline \multirow{3}{*}{\multicolumn{2}{|c|}{ Type of Tissue }} & \multicolumn{3}{|c|}{ Type of Wound } & \multirow{3}{*}{$\begin{array}{c}\text { Total } \\
\text { No. of } \\
\text { Patients }\end{array}$} \\
\hline & & \multirow{2}{*}{$\begin{array}{l}\text { Perforated } \\
\text { No. }\end{array}$} & \multirow{2}{*}{$\begin{array}{l}\begin{array}{l}\text { Destructive } \\
\text { Perforated }\end{array} \\
\text { No. }\end{array}$} & \multirow{2}{*}{$\begin{array}{c}\begin{array}{c}\text { Highly } \\
\text { Destructive }\end{array} \\
\text { No. }\end{array}$} & \\
\hline & & & & & \\
\hline \multirow{3}{*}{ Soft Tissue Only } & High & 5 & 5 & 0 & 10 \\
\hline & Low & 9 & 1 & 0 & 10 \\
\hline & Total & 14 & 6 & 0 & 20 \\
\hline \multirow{3}{*}{$\begin{array}{c}\text { Bone And Soft } \\
\text { Tissue }\end{array}$} & High & 0 & 2 & 8 & 10 \\
\hline & Low & 2 & 4 & 4 & 10 \\
\hline & Total & 2 & 6 & 12 & 20 \\
\hline
\end{tabular}

Chi-Square Tests

\begin{tabular}{c|c|c|c|c}
\hline \multicolumn{2}{c|}{ Tissue } & Value & df & p-value \\
\hline Soft Tissue Only & Pearson Chi-Square & 3.810 & 1 & 0.051 \\
\hline $\begin{array}{c}\text { Bone and Soft } \\
\text { Tissue }\end{array}$ & Pearson Chi-Square & 4.000 & 2 & 0.135
\end{tabular}


Table (7): the Relation between the Factor of Morbidity (Velocity of Bullet) and Type of Wound

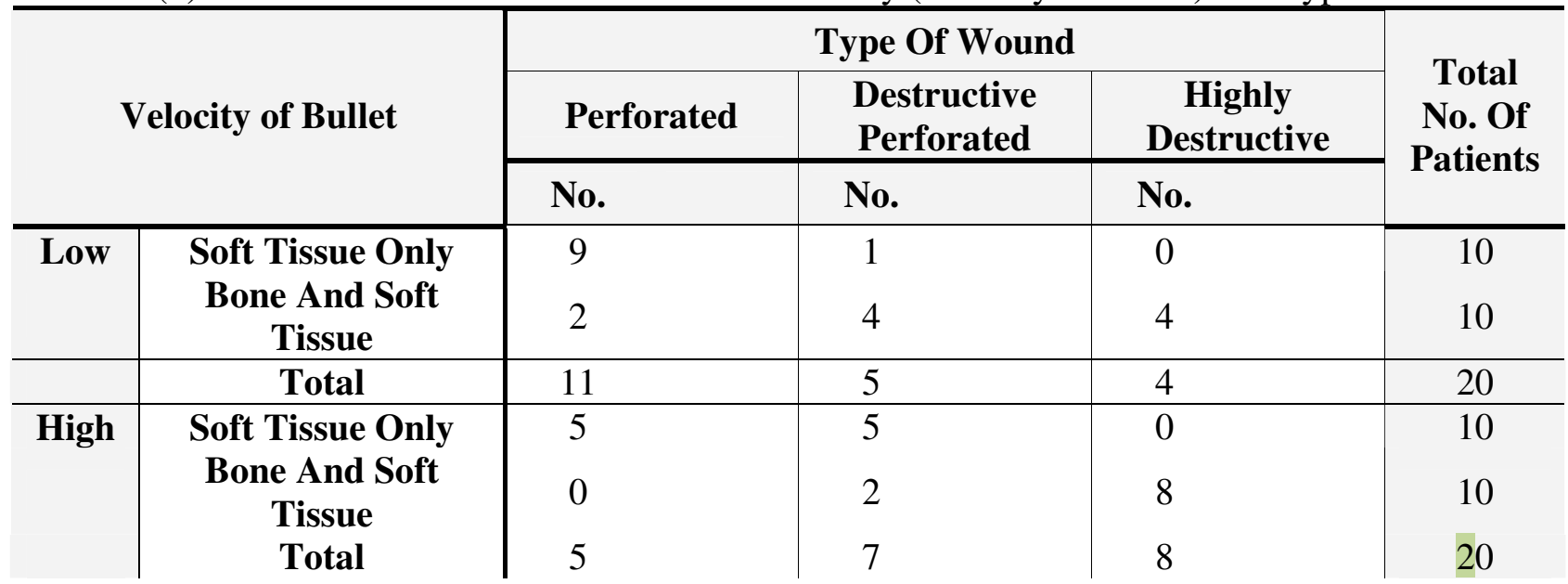

Chi-Square Tests

\begin{tabular}{c|l|c|c|c}
\hline \multicolumn{2}{|c|}{ Velocity } & Value & Df & P-Value \\
\hline Low & Pearson Chi-Square & 10.255 & 2 & $0.006^{* *}$ \\
\hline High & Pearson Chi-Square & 14.286 & 2 & $0.001^{* * *}$
\end{tabular}

The statistical analysis showed that there was no significant difference between the morbidity of high and low bullet velocity that involves the soft tissue only; also there was no significant difference between the morbidity of high and low bullet velocity that involves the bone and soft tissue. The statistical analysis showed a highly significant difference between the morbidity of soft tissue only and the soft tissue with bone involvement by low bullet velocity. There was also a very highly significant difference between the morbidity of soft tissue only and the bone with soft tissue involvement by high bullet velocity.

\section{DISCUSSION}

In the results reported by this study, it is noticed that the victims were distributed in a wide range of age ( 4 month -77 years). This gives an idea about the high risk style of life in which any person can be affected by missile injuries; mainly males (78\%) as some are weapon bearers and are out of the house more than females.

The study showed different types of bullets in shape, size and composition were used, and this diversity of bullets demonstrates the diversity of the weapons used. The most common type was the classical one (67\%) which may be due to the widespread use weapons that use this type of bullets among people during the previous Iraqi wars.

The study describes a classification for the causes of injuries resulting from explosions, with the most common cause from shells and fragments of blast material (40\%) as shells are scattered in all directions and travel a long distance with different speed. The blast wave was the less cause $(6.5 \%)$ because it affects only a person who is close to an explosion; this category corresponds to the reports contents of Hull ${ }^{(8)}$, Horrocks ${ }^{(9)}$ and Wani ${ }^{(11)}$ that reported the explosions will cause injury through three principle mechanisms: primary blast injury, secondary injury, and tertiary injury. Primary blast injury is caused by the effect of the blast wave or pressure wave on the body. Secondary injury is the result of debris propelled by the blast wind of 
the explosion. These flying projectiles can produce both penetrating and blunt trauma. Finally, tertiary injuries are caused by the displacement of the body by the blast winds into environmental objects.

Unfortunately, and within limits of this study we did not find a classification in the previous studies that involves all types of wounds in our cases in the present research, for example, Matheson ${ }^{(3)}$ reported that the local effects of missile injury of tissue are laceration and crushing, production of shock wave and temporary cavitation, while Hollerman ${ }^{(12)}$, Fackler ${ }^{(13)}$, Malcolm ${ }^{(14)}$ and Christina-Athanasia ${ }^{(15)}$ reported that missiles are passing through tissue by crush and stretch. Tissue crush is the crushing of the tissue struck by the projectile (forming the permanent cavity); while tissue stretch refers to the radial stretching of the projectile path walls (during temporary cavity formation).All these reports did not give a good idea about wound condition, and in an attempt by this study, a specific classification that describes and determines the types of injury and their treatment is shown. The most common missile wounds was the penetrated type $(30 \%)$ because it may result from the most common causes of injuries that include shells and foreign bodies mainly when they became small size with low velocity. While the highly destructive wound was the less common type (8\%), this may be due to special conditions (missile with high energy, bone involvement) that produce this type of wound.

The low velocity missiles could enter the body through the soft tissue from a small wound (inlet) and leave the body through a small wound (exit) that results in a perforated wound $(90 \%)$ in which there was tissue damage along the soft tissue tract of bullet without tissue loss. This result agrees with the study of Salam ${ }^{(16)}$ which showed that low velocity missile wounds are entirely localized in which the tissues affected are those which come in contact with the missile, entry and exit wounds are small and usually more or less similar in size.

High velocity bullets that are fired from different automatic weapons enter the body through the soft tissue from small wound (inlet) and leave the body through a large and irregular wound (exit) that results in perforated wound $(50 \%)$ and destructive perforated wound $(50 \%)$ in which there was damage and loss of soft tissue along the bullet tract and exit side. This result agrees with El Shourbagy ${ }^{(17)}$ who reported that tissue destruction will be more severe in high velocity missiles, in which the tissues are flung away from the missile's track, cavitation, rupture of blood vessels and nerves may take place in parts distal from the site of the path.

Low and high velocity missiles when involving bone, will lead to explosion of bone, high energy transfer to tissue, wide distribution of bone shells, severe damage and loss of soft and hard tissue resulting mainly in highly destructive wound (80\% in high velocity, $40 \%$ in low velocity). The study showed a highly significant difference between the morbidity of soft tissue only and soft tissue with the bone involvement by low bullet velocity, and there was very highly significant difference between the morbidity of soft tissue only and the bone with soft tissue involvement by high bullet velocity. These results disagree with Cooper ${ }^{(4)}$, Ordog ${ }^{(18)}$ and Bartlett ${ }^{(19)}$ whom reported that the missile velocity is the single most important factor in creating a wound which usually is classified as either low-velocity or high-velocity. On the opposite side, it agree with Fackler ${ }^{(20)}$ and Ryan ${ }^{(6)}$ who said it is wrong to think that one can predict the wound produced according to whether a bullet is "high velocity" or "low velocity." Bullet velocity is only one factor in wounding and in some wounds it may be a minor factor. Kinetic energy expended in elastic tissue may produce little damage, as tissue stretch may be well tolerated. It also agrees with Christina-Athanasia ${ }^{(15)}$ who recorded that the ability of different tissues to survive this blunt trauma is related primarily to tissue elasticity and cohesiveness. 


\section{CONCLUSION}

The present research placed a new specific classification for missile wounds determines their management and classifies the missiles that are extracted from the body and determining the causes of injuries that result from explosions. The study concluded that the morbidity of missile injury in the maxillofacial region depends on the type of tissue involvement more than the missile velocity.

\section{REFERENCES}

1. Cruse P. The benefits of war-to surgery. Can J Surg. 1985; 28-102.

2. Kelly JF. Management of war injuries to the jaws and related structures. Washington DC, 1979; 8-19.

3. Matheson M. Missile Wounds. Sing Med J. 1969. 10:56-59.

4. Cooper GJ, Ryan JM. Interaction of penetrating missiles with tissues: Some common misapprehensions and implications for wound management. Br J Surg.1990; 77-606.

5. Alexandropoulou C E, Panagiotopoulos E E. Traumatic ballistic: Analysis of parameters and confrontation of wounds caused from missiles in human body. Hell J Nur Sci. 2009. 2(2): 30-34.

6. Ryan J M, Biant L. Gunshot wounds and blast injury. In: Greaves I, Porter K. Prehospital Medicine: The principles andpractice of immediate care. London: Arnold: 1999: 363-373.

7. Staply S A, Cannon L B. An overview of the pathophysiology of gunshot and blast injury with resuscitation guidelines. 2006. 20:322-332.

8. Hull JB, Cooper GJ. Pattern and mechanism of traumatic amputation by explosive blast. J Trauma. 1996. 40:S198-205.

9. Horrocks CL. Blast injuries: biophysics, pathology and management principles. J R Army Med Corps. 2001. 147:28-40.

10. Skokljev A. Mass-scale integral care of wounds in the maxillofacial region. Med CorInt J. 1987; 5:5-13.

11. Wani I, Gilkar L, Mir I, Rather M, Ahmed M N.: Blast Injury: brief review article. Int J Res Dis Med. 2007. 7:76-99.

12. Hollerman J J. Gunshot wounds: radiology and wound ballistics: The Klein Memorial Lecture. Eme Rad. 1995. 2:92-171.

13. Fackler M L. Civilian gunshot wounds and ballistics: dispelling the myths. Emerg Med Clin North Am 1998; 16:17-28.

14. Malcolm J D. Terminal Ballistics: A text and atlas of gunshot wounds, 2006. 22-65.

15. Alexandropoulou CA and Panagiotopoulos E. Wound Ballistics: analysis of blunt and penetrating trauma mechanisms, Hea Sci J. 2010; 4:166-173.

16. Salama OMM. Osseointegrated implants in supporting craniofacial prosthesis for rehabilitation of war injuries. Cairo, Milittary Medical Academy, Egy Mil Med J. 1999.

17. El Shourbagy WAA. The October war wounds, wound ballistics and evaluation of their surgical treatment. Egy Mil Med J. 1984.

18. Ordog GJ, Wasserberger J, Balasubramaniam S. Shotgun wound ballistics. J Trauma.1988. 28:31-624.

19. Bartlett CS, Helfet DL, Hausman MR, Strauss E. Ballistics and gunshot wounds: effects on musculoskeletal tissues. J Am Aca Ort Surg. 2000. 8:21-36.

20. Fackler M.L. Civilian gunshot wounds and ballistics: dispelling the myths. Emerg Med Clin North Am.1998. 16:17-28. 